\title{
Assessment of rheumatoid activity based on clinical features and blood and synovial fluid analysis
}

\author{
MARGARET FARR, M. J. KENDALL, D. W. YOUNG, M. J. MEYNELL, AND \\ C. F. HAWKINS \\ From Queen Elizabeth Hospital, Edgbaston, Birmingham B15 2TH
}

\begin{abstract}
Farr, M., Kendall, M. J., Young, D. W., Meynell, M. J., and Hawkins, C. F. (1976). Annals of the Rheumatic Diseases, 35, 163-167. Assessment of rheumatoid activity based on clinical features and blood and synovial fluid analysis. Joint inflammation in rheumatoid arthritis has been assessed, and the most useful guides to disease activity were determined by analysis of synovial fluid and blood together with the history of joint disability. The patient's own evaluation of the amount of pain suffered was the most useful clinical assessment. Differential cell count and glucose estimations were the most helpful guides in the synovial fluid, while C-reactive protein in the serum most accurately reflected disease activity. The effects of systemic steroids on these indices were studied, and the differences between seronegative and seropositive patients noted.
\end{abstract}

Evaluation of the rheumatoid patient depends upon having objective and reproducible measures of disease activity, and efficiency of therapy should be judged on its ability to control that activity. A simple measure of the intensity of inflammation would be invaluable. No such ideal parameter now exists, but assessments based on symptoms and signs, haematological and biochemical values, and changes in plethysmographic, thermographic, and isotope clearance measurements can be made (Hart and Huskisson, 1972).

A careful clinical assessment which may be converted into a numerical score has been used for many years as a measure of disease activity. Many techniques are described, some complex (Lansbury, 1958) and others less so (Ritchie and others, 1968), all requiring the patient's co-operation, a skilled examiner, and time in a busy clinic. The erythrocyte sedimentation rate (ESR) is most commonly used, but it is better to measure $\mathrm{C}$-reactive protein and haptoglobin (McConkey, Crockson, and Crockson, 1972) or plasma fibrinogen (Takeda, 1967). Levels of other proteins, particularly immunoglobins (Ig) A and G (Schur and Sandson, 1963; Veys and Claessens, 1968), have been measured, and biochemical values such as serum iron, alkaline phosphatase, and 5-nucleotidase (Kendall and others, 1970), have been used.

Disease activity can also be assessed by analysing synovial fluid. The white cell count is raised in in- flamed joints (Ropes and Bauer, 1953). The more acute the inflammation the higher the absolute and percentage polymorph counts, and a direct correlation exists between synovial inflammation and percentage polymorph counts (Farr and others, 1973). Glucose concentration and fluid viscosity (Ropes and Bauer, 1953) are both reduced in inflamed joints, while levels of acid phosphatase and $\beta$-acetylglucosaminase (Caygill and Pitkeathly, 1966), 5-nucleotidase (Kendall and others, 1971), and both IgG and IgA (Panush, Bianco, and Schur, 1971) are raised.

In this investigation certain facets of the history of joint disability and simple measurements on synovial fluid and blood from patients with rheumatoid disease were assessed to determine which are related to clinical activity and which are most useful. Since no ideal measure of inflammatory activity exists with which to compare our assessments, we have used an arbitrary grading of activity based on the cardinal clinical signs of inflammation.

\section{Patients and methods}

\section{PATIENTS}

Ninety-two patients referred from the general outpatient clinic because joint effusions (124) were the main problem were studied. They were otherwise unselected. Fifty-eight were female and the mean age was $50 \cdot 3$ years (range 18-73 years). According to the A.R.A. classification (Ropes and others, 1959) 57 were judged classical, 23 definite, and 12 probable. 
CLINICAL ASSESSMENT

A detailed history was taken with particular reference to the patient's complaints about the affected joints. Duration of the illness, of the symptoms in the swollen joints, and of early morning stiffness was noted, as well as drug intake, number of joints involved, and degree of deformity. Patients' assessment of the amount of pain they experienced was recorded. Appropriate $x$-rays were taken.

Clinical activity of the joints was then assessed by one of us (M.F.) on an arbitrary scale before blood and synovial fluid specimens were taken. The amount of pain on joint movement, amount of stiffness, and the amount of swelling due to fluid or soft tissue involvement were assessed on examination and each allocated a score as follows: nil $=0$, mild $=1$, moderate $=2$, severe $=3$. One point each was also given if heat, redness, and tenderness were present. Individual scores were then totalled to give the activity index (in 3 grades) $1-3=$ mild, $4-7=$ moderate, over $8=$ severe, with which measurements in the synovial fluid and blood and other clinical information were then compared.

Because joint effusion was the main problem in our patients, the severity of the inflammation in the worst joint was considered to be the best guide to disease activity in that particular patient at the time of assessment. In order to assess the effect of systemic steroids, the patients were divided into 2 groups of those receiving steroid therapy (24) and those not receiving steroids (96). In addition, the seropositive (Rose-Waaler titre $>1: 32$ ) and seronegative patients were compared.

\section{ANALYSES OF BLOOD}

Full blood count, ESR (Westergren), biochemical profile including alkaline phosphatase, proteins, albumin and globulin, serum aspartate aminotransferase, 5-nucleotidase by the method of Persijn and others (1968), Creactive protein by the method of Crockson (1963), fibrinogen by the immunonephelometric (Farrell and Wolf, 1972) and clottable methods (Farrell and Wolf, 1971), IgG, IgM, IgA, and IgD (Mancini, Carbonara, and Heremans (1965), Rose-Waaler, and latex slide tests were carried out.

\section{ANALYSIS OF SYNOVIAL FLUID}

Total white cell count (WBC) and red cell count (RBC), differential WBC, glucose, acid phosphatase on whole and supernatant fractions of fluid, 5-nucleotidase in the supernatant fraction, immunoglobulins as above, Rose-Waaler, and latex slide tests were carried out.

\section{STATISTICAL ANALYSIS}

Correlation coefficients were calculated for each item of data (clinical, blood, and synovial fluid) and the activity index. Correlations which attained a significance level of $\mathbf{P} \leqslant 0.05$ and those which approached statistical significance are included in Tables I-III. Other associations are mentioned in the text. Analysis was carried out using Spearman's method (Keeping, 1962) as implemented in the Statistical Package for the Social Sciences, and run on the University of Birmingham 1906A ICT Computer.

\section{Results}

Table I summarizes the clinical information, synovial fluid and blood data which correlate with disease activity. The data, which are set out in three columns depending on the value of the correlation coefficients and the possible usefulness of the associations, emphasize the value of the patient's assessment of the pain, the synovial white cell count and glucose, and the C-reactive protein in the blood. The following were not significantly $(P>0 \cdot 1)$ correlated with activity: length of early morning stiffness, total duration of

Table I Correlations between activity index and other variables

\begin{tabular}{|c|c|c|c|c|c|c|}
\hline \multirow[t]{2}{*}{ Parameters } & \multicolumn{2}{|l|}{$I$} & \multicolumn{2}{|l|}{ II } & \multicolumn{2}{|l|}{$I I I$} \\
\hline & Possible interest & $\begin{array}{l}r= \\
0.1-0.2\end{array}$ & Probably clinically relevant & $\begin{array}{l}r= \\
0.2-0.4\end{array}$ & Clinically relevant & $\begin{array}{l}r= \\
0 \cdot 4+\end{array}$ \\
\hline \multirow{2}{*}{$\begin{array}{l}\text { Clinical } \\
\text { features }\end{array}$} & No. of painful joints & $0 \cdot 1486$ & & & \multirow{2}{*}{$\begin{array}{l}\text { Patient's assessment } \\
\text { of pain }\end{array}$} & \multirow{2}{*}{0.4943} \\
\hline & Degree of deformity & $0 \cdot 1936^{*}$ & & & & \\
\hline \multirow[t]{3}{*}{$\begin{array}{l}\text { Synovial } \\
\text { fluid }\end{array}$} & \multirow{3}{*}{$\begin{array}{l}\text { Red cell count } \\
\text { Absolute monocytes } \\
\text { Absolute synovial } \\
\text { cells } \\
\text { Acid phosphatase } \\
\text { supernatant } \\
\text { Rose-Waaler titre } \\
\text { IgG } \\
\text { IgM }\end{array}$} & $\begin{array}{l}0 \cdot 1590 \\
0 \cdot 1301\end{array}$ & $\begin{array}{l}\text { White cell count } \\
\% \text { Monocytes }\end{array}$ & $\begin{array}{l}0.3823 \\
0.3603\end{array}$ & \multirow{2}{*}{$\begin{array}{l}\% \text { Polymorphs } \\
\% \text { Lymphocytes } \\
\text { Absolute } \\
\text { polymorphs }\end{array}$} & $\begin{array}{r}0.5225 \\
-0.4804\end{array}$ \\
\hline & & $0 \cdot 1030$ & \multirow{2}{*}{$\begin{array}{l}\text { 5-Nucleotidase } \\
\text { Acid phosphatase } \\
\text { whole } \\
\text { IgA }\end{array}$} & 0.3036 & & 0.4572 \\
\hline & & $\begin{array}{l}0 \cdot 1006 \\
0 \cdot 1071 \\
0 \cdot 1194 \\
0 \cdot 1611\end{array}$ & & $\begin{array}{l}0 \cdot 3207 \\
0 \cdot 2123\end{array}$ & Glucose & -0.4255 \\
\hline Blood & $\begin{array}{l}\text { Haemoglobin } \\
\text { Fibrinogen (I). }\end{array}$ & $\begin{array}{l}0 \cdot 1733^{*} \\
0 \cdot 1259\end{array}$ & $\begin{array}{l}\text { ESR } \\
\text { Fibrinogen (C) }\end{array}$ & $\begin{array}{l}0 \cdot 2954 \\
0 \cdot 2863\end{array}$ & & \\
\hline Serum & $\begin{array}{l}\text { Albumin } \\
\text { Globulin } \\
\text { SGOT }\end{array}$ & $\begin{array}{l}0 \cdot 1903 \\
0 \cdot 1420 \\
0 \cdot 1366\end{array}$ & 5-Nucleotidase & -0.3064 & C-reactive protein & 0.4163 \\
\hline
\end{tabular}

In columns II and III all the indices are highly significant $(P<0.001)$ except for IgA $(P<0 \cdot 01)$.

In column I those marked with * are significant $(P<0 \cdot 05)$. 
disease and the duration of disease in the affected joint, serum alkaline phosphatase, serum RoseWaaler titre and immunoglobulins, white cell count in the blood, and absolute lymphocyte count in the synovial fluid.

Since steroids influence the inflammatory process the variables which correlate with clinical activity in patients on steroid therapy and in patients not on steroids have been determined separately (Table II). Some variables are of value in both groups, but blood C-reactive protein, haemoglobin, and ESR and synovial glucose appear to be useful guides only in patients not on steroids.
Unfortunately, the correlation coefficients in most instances are low, presumably because factors other than disease activity (such as character of the disease, drugs, and age) also exert an influence, and there may be some interaction between variables being measured. All those in Table II were significantly correlated with disease or joint activity $(P<0.05)$.

For comparison, the same data for the seropositive and seronegative patients are given in Table III. In seropositive subjects there was a direct correlation of Rose-Waaler titre and an inverse relationship between the levels of serum 5-nucleotidase, albumin, and serum aspartate aminotransferase (SGOT), and dis-

Table II Effect of systemic steroids on correlations between activity index and other variables

\begin{tabular}{|c|c|c|c|c|c|c|}
\hline & Steroid group & $r$ & Nonsteroid group & $r$ & $\begin{array}{l}\text { Steroid group }(S) \text { and } \\
\text { nonsteroid group }(N S)\end{array}$ & $\begin{array}{l}r \underset{N S}{S} \\
r N\end{array}$ \\
\hline \multirow[t]{3}{*}{ Blood } & Fibrinogen (I) & 0.4637 & C-reactive protein & 0.4356 & 5-Nucleotidase & $\begin{array}{r}-0.4697 \\
0.2239\end{array}$ \\
\hline & IgG & $0 \cdot 3850$ & Haemoglobin & -0.2498 & \multirow{2}{*}{$\operatorname{Ig} A$} & \\
\hline & Rose-Waaler titre & 0.3543 & ESR & 0.2452 & & $-0 \cdot 1846$ \\
\hline \multirow[t]{5}{*}{ Fluid } & Rose-Waaler titre & 0.5374 & \multirow[t]{5}{*}{ Glucose } & \multirow[t]{5}{*}{$-0 \cdot 1929$} & $\%$ Polymorphs & \multirow{5}{*}{$\begin{array}{c}0.6188^{*} \\
0.4994^{*} \\
-0.5794^{*} \\
-0.4188^{*} \\
-0.5137 \\
-0.3020 \\
0.5104^{*} \\
0.4598 \\
0.4514 \\
0.3926^{*} \\
0.3758 \\
0.1907\end{array}$} \\
\hline & Red cell count & 0.4684 & & & $\%$ Lymphocytes & \\
\hline & $\begin{array}{l}\text { IgM } \\
\text { IgA } \\
\text { Absolute monocytes }\end{array}$ & $\begin{array}{l}0 \cdot 3857 \\
0 \cdot 3827 \\
0 \cdot 3473\end{array}$ & & & $\begin{array}{l}\% \text { Monocytes } \\
\text { Absolute polymorphs }\end{array}$ & \\
\hline & & & & & Total WBC & \\
\hline & & & & & 5 Nucleotidase & \\
\hline
\end{tabular}

All indices significant $(P<0.05)$, those marked with $*(P<0.001)$.

Table III Correlations between activity index and other variables in seronegative and seropositive patients

\begin{tabular}{|c|c|c|c|c|c|c|}
\hline & Seronegative patients & $r$ & Seropositive patients & $r$ & $\begin{array}{l}\text { Both seronegative } \\
\text { and seropositive }\end{array}$ & $\begin{array}{l}r \text { sero- } \\
r \text { serot }\end{array}$ \\
\hline \multirow[t]{2}{*}{ Blood } & & & 5-Nucleotidase & & C-reactive protein & $\begin{array}{l}0.4798 * \\
0.2953\end{array}$ \\
\hline & & & $\begin{array}{l}\text { Albumin } \\
\text { SGOT }\end{array}$ & $\begin{array}{l}-0.3139 \\
-0.2751\end{array}$ & ESR & $\begin{array}{l}0 \cdot 2368 \\
0 \cdot 2409\end{array}$ \\
\hline \multirow[t]{2}{*}{ Fluid } & & & & & $\%$ Polymorphs & $0.6608^{*}$ \\
\hline & $\begin{array}{l}\% \text { Monocytes } \\
\text { Acid phosphatase whole } \\
\text { IgM }\end{array}$ & $\begin{array}{r}-0.4592 \\
0.2624 \\
0.2622\end{array}$ & $\begin{array}{l}\text { Glucose } \\
\text { Rose-Waaler titre }\end{array}$ & $\begin{array}{r}-0.3511 \\
0.3291\end{array}$ & $\begin{array}{l}\% \text { Lymphocytes } \\
\text { Absolute polymorphs } \\
\text { Total white cell count } \\
\text { 5-Nucleotidase }\end{array}$ & $\begin{array}{l}0 \cdot 5890^{*} \\
0 \cdot 3302 \\
0 \cdot 5532^{*} \\
0 \cdot 3471 \\
0 \cdot 4990^{*} \\
0 \cdot 2874 \\
0 \cdot 3017 \\
0 \cdot 2250\end{array}$ \\
\hline
\end{tabular}


ease activity. Synovial fluid cytology and 5-nucleotidase were related to activity in both subgroups.

\section{Discussion}

A high polymorphonuclear count and low glucose level in synovial fluid are the best evidence for an inflammatory reaction in the joint. The fall in percentage lymphocyte and monocyte counts simply reflects the increasing proportion of polymorphs, absolute counts of each being unaffected. Estimation of enzyme concentration seems to be less valuable though acid phosphatase levels are increased in the synovial fluid of patients with inflammatory arthropathies, particularly those with classical rheumatoid disease (Caygill and Pitkeathly, 1966). The relevance of the higher levels seen in the more active forms must remain uncertain, but they are probably secondary to the increased leucocyte count. Synovial 5-nucleotidase is derived principally from the synovial cells and is increased in inflamed joints (Farr and others, 1973). Raised levels of this enzyme probably result from the pathological process in the synovial membrane.

Serum immunoglobulin concentrations and RoseWaaler titres were of little value in assessing the intensity of the joint inflammation in our patients. However, Claman and Merrill (1966) and Marcolongo and others (1967) found that IgA was raised in the serum, but whereas the former workers found it correlated with an increased ESR, the latter group found no association with clinical activity. Veys and Claessens (1968) showed that IgG and IgA were increased in the serum and claimed some association with activity. Panush and others (1971) found raised synovial immunoglobulins, especially IgG and IgA, in some patients with rheumatoid disease and claimed a relationship with clinical activity of the joint. Our results do not clarify the position, and the interpretation of immunoglobin levels in the synovial fluid and serum remains a problem. Synovial fluid viscosity is also a guide to disease activity and since intraarticular inflammation reduces the viscosity of synovial fluid it has been used in assessment of antiinflammatory drugs in rheumatoid arthritis by Holt and others (1968).

The value of acute phase proteins has been described by McConkey and others (1972) who suggested that C-reactive protein and haptoglobin levels were more reliable than ESR. We did not measure haptoglobin levels but our study shows clearly that $\mathrm{C}$-reactive protein is the best parameter measured in the blood. Fibrinogen, another acute phase protein, is present in increased amounts in rheumatoid disease owing to an increased synthetic rate which is proportional to the disease activity. The serum 5-nucleotidase, in contrast to the 5-nucleotidase in synovial fluid, is inversely proportional to activity - the reason for this is unknown.
The patient's own assessment of the severity of the pain was the only part of the disease history which correlated with clinical activity. The visual analogue scale has proved a satisfactory way of self-rating pain intensity (Joyce and others, 1975), and perhaps should be used more widely in rheumatology clinics to monitor the progress of the disease. It is much simpler to administer than thermography (Collins and others, 1974), and isotope studies such as technetium uptake (Dick and others, 1970a) and xenon clearance (Dick and others, 1970b), which are more objective than clinical examination, but require skills and equipment available only in specialized centres.

The effect of steroids on the activity indices was interesting. The conventional ESR and the newer C-reactive protein estimations correlated significantly with activity only in those patients not on steroids. By contrast, the immunonephelometric fibrinogen level appeared to be of little value in the patients as a whole, but should perhaps be used for patients on steroids instead of the ESR or C-reactive protein. Similarly, the Rose-Waaler titre in synovial fluid correlated well with activity in patients on steroids, a surprising and unexplained result.

The interesting finding in the patients divided into seropositive and seronegative groups was that in the former increasing activity was associated with decreasing levels of serum 5-nucleotidase, albumin, and SGOT. These are all proteins synthesized in the liver and the low levels may be due to impairment of liver function (Kendall and others, 1970). Alternatively, the low levels may result from increased catabolism which is known to affect both albumin (Ballantyne, Fleck, and Dick, 1971) and IgG (Watkins and Swannell, 1974).

We have shown that four parameters most accurately reflect disease activity in patients with rheumatoid disease: (1) the patient's own assessment of the amount of joint pain, (2) polymorph count and (3) glucose estimation on the synovial fluid, and (4) serum C-reactive protein estimation, though other variables may be more useful in patients on steroids. Though there are many ways of assessing joint inflammation which are all complex and require skill and sophisticated equipment, our four indices are simple and should assist those who wish to assess progress or gauge the efficacy of drugs.

We are particularly grateful to Miss Marjorie Emery for assistance, and to the staff of the haematology, clinical chemistry, and immunochemistry departments for carrying out estimations on blood and synovial fluid specimens; also to Dr. P. Wolf and G. Farrell for fibrinogen determinations, and to R. A. and A.P. Crockson for C-reactive protein estimations. We thank Professor K. W. Walton for his advice and encouragement. The work was in part supported by a grant from the Arthritis and Rheumatism Council for Research. 


\section{References}

Ballantyne, F. C., Fleck, A., And Dick, W. C. (1971) Ann. rheum. Dis., 30, 265 (Albumin metabolism in rheumatoid arthritis)

Caygill, J. C., AND PitKeathly, D. A. (1966) Ibid., 25, 137 (A study of $\beta$-acetylglucosaminase and acid phosphatase in pathological joint fluids)

Claman, H. N., AND Merrill, D. A. (1966) J. Lab. clin. Med., 67, 850 (Serum immunoglobulins in rheumatoid arthritis)

Collins, A. J., Ring, E. F. J., Cosh, J. A., And Bacon, P. A. (1974) Ann. rheum. Dis., 33, 113 (Quantitation of thermography in arthritis using multi-isothermal analysis)

Crockson, R. A. (1963) J. clin. Path., 16, 287 (A gel diffusion precipitin method for the estimation of C-reactive protein)

Dick, W. C., Neufelt, R. R., Prentice, A. G., Woodburn, A., Whaley, K., Nuki, G., and Buchanan, W. W. (1970a) Ann. rheum. Dis., 29, 135 (Measurement of joint inflammation; a radioisotope method)

- , Whaley, K., St. Onge, R. A., Downie, W. W., Boyle, J. A., Nuki, G., Gillespie, F. C., And Buchanan, W. W. (1970b) Clin. Sci., 38, 123 (Clinical studies on inflammation in human knee joints: Xenon $\left({ }^{133} \mathrm{Xe}\right)$ clearances correlated with clinical assessment in various arthritides and studies on the effect of intra-ariicularly administered hydrocortisone in rheumatoid arthritis)

Farr, M., Kendall, M. J., Shuttleworth, R., Meynell, M. J., and Hawkins, C. F. (1973) Ann. rheum. Dis., 32, 326 (Source and significance of 5-nucleotidase in synovial fluid)

FarRell, G. W., AND Wolf, P. (1971) J. med. Lab. Technol., 28, 310 (The measurement of fibrinogen and its derivatives: I. Examination of methods of measurement of clottable fibrinogen) in plasma)

HART, F. D., AND HusKisson, E. C. (1972) Lancet, 1, 28 (Measurement in rheumatoid arthritis)

Holt, P. J. L., How, M. J., Long, V. J. W., AND Hawkins, C. F. (1968) Ann. rheum. Dis., 27, 264 (Muccopolysaccharides in synovial fluid)

Joyce, C. R. B., Zutshi, D. W., Hrubes, V., ANd Mason, R. M. (1975) Europ. J. clin. Pharmacol., 8, 415 (Comparison of fixed interval and visual analogue scales for rating chronic pain)

KeEPING, E. S. (1962) 'Introduction to Statistical Inference', p. 309. Van Nostrand, London

Kendall, M. J., Cockel, R., BeCKer, J., ANd Hawkins, C. F. (1970) Ann. rheum. Dis., 29, 537 (Raised serum alkaline phosphatase in rheumatoid disease)

- , FARR, M., Bold, A. M., AND HAWkins, C. F. (1971) Lancet, 2, 1012 (5-nucleotidase in the serum and synovial fluid of patients with rheumatoid disease)

LansBury, J. (1958) Ann. rheum. Dis., 17, 101 (Numerical method of evaluating the status of rheumatoid arthritis)

McConkey, N., Crockson, R. A., AND Crockson, A. P. (1972) Quart. J. Med., 41, 115 (The assessment of rheumatoid arthritis)

Mancini, G., Carbonara, A. O., and Heremans, J. F. (1965) Immunochemistry, 2, 235 (Immunochemical quantitation of antigens by single radial immunodiffusion)

Marcolongo, R., JR., Carcassi, A., Frullini, F., Bianco, G., And Bravi, A. (1967) Ann. rheum. Dis., 26, 412 (Levels of serum immunoglobulins in patients with rheumatoid arthritis)

Panush, R. S., Bianco, N. E., AND Schur, P. H. (1971) Arthr. and Rheum., 14, 737 (Serum and synovial fluid IgG, IgA and IgM antigammaglobulins in rheumatoid arthritis)

Persijn, J. P., Van Der Slik, W., Kramer, K., AND de Ruitjer, C. A. (1968) Z. klin. Chem., 6, 441 (A new method for the determination of serum nucleotidase)

Ritchie, D. M., Boyle, J. A., Mcinnes, J. M., Jasani, M. K., Dalakos, T. G. Grieveson, P., and Buchanan, W. W. (1968) Quart. J. Med., 37, 393 (Clinical studies with an articular index for the assessment of joint tenderness in patients with rheumatoid arthritis)

Ropes, M. W., AND BAUER, W. (1953) 'Synovial Fluid Changes in Joint Disease', p. 53. Harvard University Press, Cam bridge, Mass

—, Bennett, G. A., Cobb, S., Jacox, R., And Jessar, R. A. (1959) Ann. rheum. Dis., 18, 49 (Diagnostic criteria for rheumatoid arthritis, 1958 revision)

SChUR, P. H., AND SANDSON, J. (1963) Arthr. and Rheum., 6, 115 (Immunologic studies of the proteins of human syno vial fluid)

TAKeDA, Y. (1967) J. Lab. clin. Med., 69, 624 (Studies of metabolism and distribution of fibrinogen in patients with rheumatoid arthritis)

Veys, E. M., and Claessens, H. E. (1968) Ann. rheum. Dis., 27, 431 (Serum levels of IgG, IgM and IgA in rheumatoid arthritis)

Watkins, J., AND SWANNELl, A. J. (1973) Ibid., 32, 247 (Catabolism of human serum IgG in health, rheumatoid arthritis and active tuberculous disease) 